Máté Szabó

\title{
Wood Industry in the Region of the Dráva at the Age of Dualism
}

\begin{abstract}
The purpose of the study. In the rapidly industrializing Hungary, the wood industry became an important economic branch in the country by the beginning of the 20th century, which also played a significant role in the country's foreign trade. This industry was extremely important in the area I studied, as the forest cover along the Dráva was above the national average, and the quality of the forest stock also had an international reputation. In the last third of the 19th century, domestic and foreign demand for wood products increased, which was accompanied by an increase in the purchase prices of wood raw materials.

Applied methods. I involved sources from monographies, employment and census records, and my own data from researches of archives. In my study I present the larger wood companies in the region, the results of the plants, the operation and extent of the industry, and their market relations. I also made a structural analysis examining the entrepreneur and its business together. Outcomes. During this period, the logistical and transportation possibilities of the region improved, as the railway lines - built almost completely until the war - networked the region. In addition to transport on the river, crossing opportunities also increased, so the raw material could reach a processing unit more and more quickly. In the age of dualism, a strong stratum of forest owners and entrepreneurs in the wood industry developed. Major wood industry enterprises were established mainly in the larger estates (Bellye, Dárda, Barcs, Berzence) or through citizenship in the territory of certain large municipalities. Outstanding among these was the Beliscian plant beyond the Dráva, which in two decades had become the largest timber company in Central Europe, employing thousands of people.
\end{abstract}

Keywords: company, wood industry, forestry, forest, Dráva

\section{Introduction}

The forest is a source of life for our Earth and the people who live on it, a community and habitat that depends on natural factors and human interventions, including soil microorganisms, terrestrial mosses, fungi, soft and woody plants, and insects, birds and wildlife. In the second half of the $19^{\text {th }}$ century, forestry and the timber industry stood out from the economic system of the Dráva region, which was motivated by the possibility of utilizing rich and high-quality forests. In my study, by "along the Dráva" I mean not only the Hungarian side after the Trianon borders were drawn, but also a significant part of the Slavonian forests in connection with historical Hungary. I do this because the owners of the Hungarian side were often also the owners of the Croatian side (Somssich, Jankovich, Schaumburg-Lippe, Habsburg, Draskovich, etc.), and their farming was not divided into the Hungarian and Croatian sides in the age of dualism. ${ }^{1}$

\section{Features and opportunities. What did the forest give to society?}

What was the Dráva region like in the $19^{\text {th }}$ century? The easiest way to formulate the answer is on the basis of the descriptions of contemporary historical statisticians. György Károly Rumy mentions in his work of 1812 that the Dráva is the largest river in Somogy, which originates in Tyrol and, passing through Carinthia and Styria, separates the three counties of Hungary, Zala, Somogy and Baranya, from Croatia and Slavonia. This river flows through sandy areas

1 Kaposi Z. (2019); Kaposi Z. (2020) 
everywhere on the border of this Somogy county, and thus it rushes at a very high speed, surrounded by shores without strength. This is due in part to its winding flow, in part to the weakness and collapse of its shores, and finally to the flooding of adjacent lands caused by water that has slowed and increased as a result of the bends. ${ }^{2}$ The river was navigable in the direction of its flow.

It was important for traditional societies to have forests of the right size and quality near which they could live, which could meet the needs of communities in a myriad of forms. What the forest gave to man varied greatly from population to population, culture to culture, or by the nature of the forests. Forests have long functioned as a source of food. Think of the myriad forms of hunting; for the role of various edible plants, berries, mushrooms. However, with the improvement of agricultural production techniques and the restriction of hunting rights and free forest living, this function declined dramatically in the $19^{\text {th }}$ century. The building materials that can be extracted from forests continued to be of great importance. ${ }^{3}$ Wood was a universal raw material until the middle of the $20^{\text {th }}$ century. Its use as a building material was of decisive importance in the case of old filling houses, masonry, beams, slats, roofing materials, planks. In addition, most of people's furniture and other household items are also made of wood. Even the lard-making industry could only come from forests. ${ }^{4}$

Wood as a market product became increasingly important during the agricultural boom that began in the 1780s. The price of wood had risen, which increased the value of forested areas. Forest incomes were very important to manors in the first half of the $19^{\text {th }}$ century. The equipment requirements of agricultural production, the construction of corn borers, barns, paddocks and stables required wood the most. For a very long time, the technical equipment was also made of wood (vane blades, wooden plows, etc.) and also furniture, telegraph poles, bridges, etc. In dam construction, the construction of birch walls also assumed wood. It can be seen from all this that there was a huge need for the forest, the trees. The increase in the price of timber in places where there was a good market was exploited by unplanned deforestation, but in the vast majority of cases no or little thought was given to reforestation. ${ }^{5}$

There were other forms of ancillary use of great importance to forest managers in the area during this period. Such was the case with acorns, which had great economic potential for acorn forests, as pigs "also fatten often on oak or beech acorns". "János Nagyváthy also wrote in his contemporary work that "the Farmer should try to make his acorns grow widely." . According to Alfred Hirsch, the region was one of the largest pig-breeding regions even at the beginning of the $20^{\text {th }}$ century. ${ }^{8}$ The collection of galls in the forests of the area was an equally important source of income, as the "gall is very natural, where there are many oaks, the weather also gives birth to many galls."

By the second half of the $19^{\text {th }}$ century, deforestation accelerated in Hungary, the main reason being the acquisition of the area needed to expand grain production. This, of course, was not new, as forests had been intensively cleared since the time of the Napoleonic economy. As early as the beginning of the $19^{\text {th }}$ century, János Nagyváthy also stated that "in the middle of the last century it was considered that it was common for the Germans to have an ax everywhere in front of the sickle. By which they wanted to say that forests should be written down and turned into arable land.

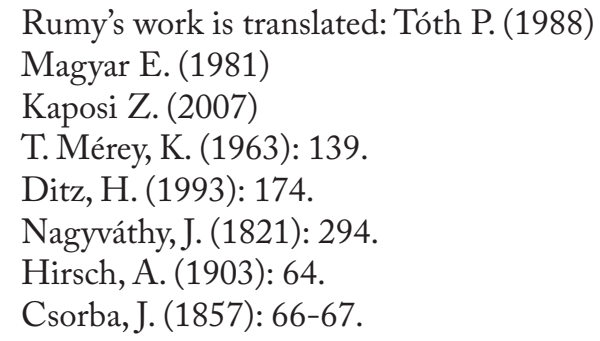


To corroborate that parable, Eckhart says that none will die because of the eclipse of the tree, but many will die in the scarcity of bread. I dare say that if Eckhart lived now and visited our more populous cities during hard winters, he would find more people suffering from the cold than hungry people: because Hungarians also think like Germans, especially in common estates in general: and in the estates of nearby forests exterminated in many places without mercy. "10 Typically in the 1870s about 3,000 acres of forest were cleared and set as arable land in the four estates of the Prince Batthyány Faith Commission, including the Nagykanizsa and Ludbreg estates along the Dráva and Mura rivers. ${ }^{11}$ In the age of large-scale deforestation, the largest price increase was observed for log products of different wood species. At the same time, unprofessional management of forests posed a great threat. The new Forest Act sought to regulate and continuously control these three factors in the management of estates.

\section{Changes in transportation options}

The railway network, which was built for over half a century, played a major role in the development of the Dráva. The Murakeresztúr-Barcs section was opened in 1868 by the Southern Railway Company, while the Pécs-Barcs section was opened by the Pécs-Barcs Railway Company. The residents of Barcs welcomed the development, and both the local and national press covered the events on the front page. The enthusiasm of the people of Barcs was not typical of those living in other settlements of Somogy county, as the line avoided the central parts of the county, including Kaposvár. The county's second railway line (the first stretched on the southern shore of Lake Balaton via the Southern Railway) was not expected to have a positive impact on the county's economy. The public opinion of the county was afraid of the influx of cheap grain from Bačka and the Great Plain, they were afraid of its market-influencing, price-reducing power. However, the rapid increase in traffic at the port and train station and the development of the city's economy proved the rightness of building the southern railway lines.

The development of the wooden bridge over the Dráva in 1883 contributed to the development of the area. From then until the construction of the railway bridge, the timber was mainly transported to Barcs by carts. Two bridges crossed the Dráva over Barcs during this period. The substructure of both bridges was stone and the superstructure was an iron structure. The length of the road bridge was $319.8 \mathrm{~m}$ and that of the railway $271 \mathrm{~m} .{ }^{12} \mathrm{Within}$ the framework of the national bridge construction program, a new $280 \mathrm{~m}$ long road bridge was built between 1902-1903 on the stone pillars sunk $20 \mathrm{~m}$ deep into the riverbed in the line of the demolished wooden bridge. Traffic was maintained by ferry during construction. The bridge was ceremoniously handed over to the traffic on 3 November, $1903 .{ }^{13}$

The development of local railways was greatly facilitated by the laws that applied to them in the 1880s. The main purpose of these was to encourage an increase in the weight of private investment in railways over public investment. The first HÉV (commuter train) that affected Barcs was the Barcs-Pakrác HÉV, which opened in $1885 .{ }^{14}$

The Hungarian section was very short, leading from the railway bridge built on the Dráva to the railway station. The purpose of the line was to connect the areas of Croatia with Barcs. The antecedent of this was the transport of timber from Slavonian oaks to Barcs. The wood delivered to Barcs was processed and transported to the western markets as a semi-finished or finished

10 Nagyváthy, J. (1821): 261.

11 Kaposi, Z. (2012); Kaposi, Z. (2013)

12 Hajós Naptár (1900)

13 Barcs és Vidéke, 3.11. 1903.

14 For the construction of Prince Schaumburg-Lippe, the owner of the Veröce estate opposite Barcs, lent the money to the state. See: Bellye (1883) 
product. Prior to the construction of the railway bridge and the railway line, the transportation of this large amount of timber was solved by floating or by ship.

The next HÉV was the line between Barcs and Somogyszob, which was handed over in 1890. One of the main goals of its construction was, among other things, to get the Széchényi (Géza and Imre) manors of Csokonya, Tarnóca, and Barcs to the railway, thus opening the more distant markets to their crops. The largest owner of the company that built and operated the line was the Széchényi family. This line helped to ensure that the products produced in the Csokonya-based estates of Széchényi could be further transported through Barcs to their largest markets. ${ }^{15}$

During this period, Barcs became a major transport hub. Additional railway lines of local interest were built. The HÉV line between Kaposvár and Barcs was completed in 1905, which, contrary to the original plans, joined the Pécs-Barcs railway not at Drávapálfalu but at Középrigóc. The next and last built HÉV was the Barcs-Sellye- Siklós line, which was opened in 1912.

Among other things, the Spanovica-Papuki forest industrial railway was built in Pakrác. This newly built railway, which is about $32 \mathrm{~km}$ long, connects to the already existing PakrácSpanovica industrial railway which was owned by the Slavonian Forest Industry Plc. This railway network, which was more than 50 kilometers long, handled the company's timber products from the forest to the steam sawmill in Pakrác with 5 locomotives and 200 wagons. The newly opened part of the line was owned by the Hungarian-Belgian Metal Industry Factory. ${ }^{16}$ The Gutmann plant in Belisce had the largest forest railway network in the region, as 800 railway cars and 9 locomotives transported the harvested timber from the surrounding forests to the plant on a 200 $\mathrm{km}$ long industrial railway system.

Thanks to the railway network of the region, both wood raw material and already processed wood material could reach their target markets faster and at lower costs. These railways made it possible to deliver products to seaports to make it more cost-effective to reach more distant markets. Sándor Engel also states in his work published in 1882 that „it is hoped that the construction of the port of Rijeka and the reasonable pricing policy of the Hungarian State Railways will soon make Rijeka an important market for French donga trade." He also mentions that the export of 1879 also took place via Rijeka, which shows that only one-thirtieth of all the production of staves in Austria-Hungary entered the world market via Rijeka. ${ }^{17}$

The creation of the technical preconditions for steamship and the need for transport of sufficient size to start economical traffic had been given since the middle of the $19^{\text {th }}$ century. Still, the steamboats were off to a slow start on the river. The main reason for this was the deregulation of the Dráva. The river also changed direction frequently and unexpectedly because of the stumps in its bed. Behind them, alluvium accumulated, creating reef islands that again only changed the direction of the flow. More and more logs were released into the water from the washed-up shores. ${ }^{18}$

These problems were overcome by significant regulatory work in the 1880s. In 1856, the first steamship appeared in Barcs, which was owned by the Danube Steamship Company (hereinafter DGT). As early as the 1860 s, a regular combined passenger-cargo line was launched. Until 1865, DGT steamers sailed from Osijek to Kakonya. It was a $229 \mathrm{~km}$ stretch. The shipments on this route were discontinued by the company in 1865, claiming that this long route was

\footnotetext{
15 Harasztia, A. (2005): 50.

16 Magyar Fakereskedő (1908)

17 Engel, S. (1882)

18 Vízügyi és Hajózási Közlöny (1907)
} 
unprofitable for it. Thereafter, DGT carried out only occasional transport between Osijek and Barcs and was only willing to transport in larger batches. ${ }^{19}$

\section{Wood industry along the Dráva}

We can find reliable data on forest cover in Hungary in the work of Albert Bedô at the beginning of the $20^{\text {th }}$ century. The official figures for 1907 based on Bedô's work were as follows:

Table 1 . Size and proportion of forests in the country at the beginning of the 20th century (ca.)

\begin{tabular}{|l|l|l|l|}
\hline a./ & - protected forest & $603.590 \mathrm{ca}$. & $4,6 \%$ \\
& - forest on quicksand & $206.581 \mathrm{ca}$. & $1,6 \%$ \\
& - forest on unconditional forest soil & $10.473 .373 \mathrm{ca}$. & $80,6 \%$ \\
& - forest not necessarily on forest soil & $1.712 .549 \mathrm{ca}$. & $13,2 \%$ \\
\hline b./ & - oak forest & $3.556 .594 \mathrm{ca}$. & $27,3 \%$ \\
& - other deciduous forest & $6.433 .521 \mathrm{ca}$. & $49,6 \%$ \\
& - pine forest & $3.005 .978 \mathrm{ca}$. & $23,1 \%$ \\
\hline c./ & - forest subject to an operational plan obligation & $8.173 .795 \mathrm{ca}$. & $62,9 \%$ \\
& - forest not subject to an operational plan obligation & $4.822 .298 \mathrm{ca}$. & $37,1 \%$ \\
\hline & Hungary total: & $12.996 .093 \mathrm{ca}$. & $100 \%$ \\
\hline & Croatia-Slavonia: & $2.659 .326 \mathrm{ca}$. & \\
\hline & In total: & $15.655 .419 \mathrm{ca}$. & \\
\hline
\end{tabular}

Source: Erdészettörténet (2011): 7.

The forest cover of Hungary in 1907 was 26.1\%. Thus 6.2\% of Hungary's forests (excluding Croatian-Slavonian countries) were protected forests that had some protective function. Furthermore, $80.6 \%$ stood on unconditional forest soil. The oak forest was a little over a quarter, the other deciduous half, the pine a little less than a quarter of the whole area. Slightly twothirds of plant management was required by law. $15.3 \%$ of the forests were state-owned, $20.1 \%$ were legislative, municipal $7.3 \%$, trust-owned and $35.1 \%$ were privately owned. ${ }^{20}$ The data show that the influence of the state was significant in the forestry industry.

Within the wood processing industry, classified according to Márta Perényi Kolossváryné, the wood industry in Hungary developed after the unfolding of the capitalist system after 1848, and its main, highest-value-producing sector became timber production. The main feature of this sub-sector was that it was linked to forest holdings by short-term contracts for the extraction of valuable natural wood raw material stocks. The source of raw materials, and industrial capital was closely related to forestry, in some vertical integration. ${ }^{21}$

This "forestry industry" in the hands of a capitalist or group of capitalists then allowed the current market conditions to be significantly used. Consequently, the statistical reporting of timber traders and timber plant owners had been less reliable from the outset, also due to circumstances that can be considered objective. Hungary's manufacturing data were recorded in two years, 1898 and 1906, and the first aspects of the wood industry were edited by József Szterényi - in 1901, ${ }^{22}$ the second - edited by Aladár Edvi Illés - were published in $1911 .{ }^{23}$ The

19 Erdősi, F. (1971)

20 http://www.emk.nyme.hu/uploads/media/Erd\%C3\%A9szett\%C3\%B6rt\%C3\%A9net 2011.pdf

Kolossváryné Perényi, M. (1978): 171.

Szterényi, J. (1901)

Edvi Illés, A. (1911) 
geographical location of the sawmills was indicated by name and it was also stated, albeit in two different ways, what gave the main profile of the plant in question. ${ }^{24}$

\section{Picture 1. An ad posted by the estate of Bellye for sale}

\section{Tüzifa-eladás.}

\begin{abstract}
A fóherczegi béllyei uradalom a Dunán és mellékágain berakható körülbelül 60.000 (hatvanezer) ürméter különböző nemủ lágy és kemény tüzifát zárt ajánlat utján ad el. Az ajánlattétel márczius hó 11-én jár le; a részletes feltételeket alulirt igazgatóság kivánatra megküldi.

Föherczegi joszágigazgatósâg Föherczeglak.
\end{abstract}

Source: Magyar Fakereskedő (1908): 26.

To exploit the valuable timber stocks, steam saws were rapidly established with the development of railway lines, first in the Highlands and Croatian-Slavonia and then in Transylvania. The development was particularly significant after the crisis of 1871-1873, when foreign capital flowed into the state in an increased manner. As reported by the Minister of Agriculture in the 1890 forestry report submitted to the Parliament, the most important branch of the "forestry industry" became the sawmill industry, which had shown great development since the enactment of the Forest Act. Comparison with the 1880s is illustrated by Albert Bedő's forestry statistics published in 1885 and $1896 .{ }^{25}$

Due to the forests along the Dráva and the transport possibilities provided by the river, there had always been a significant amount of wood industry capacity in this area. As mentioned earlier, wood was a universal product, meaning that its processing was important to both the estates and the people of the area. Between 1882 and 1913, the traditional forest wood selections were building and instrumentation, donga, sleepers, firewood, and charcoal. The secondary wood industry was poorly developed and highly artisanal in nature. According to the industrial statistics of the time, among the sub-sectors of the wood industry performing secondary processing, the production of parquet and the production of bent furniture stood out the most. After the sawmill industry, the largest production values were provided by the joinery group. ${ }^{26}$

The economic development of the $19^{\text {th }}$ century, the expansion of the large-scale plants, brought with it an increase in the demand for building materials, so it is no coincidence that the lords sought to establish their own wood-based plants. The initial form of this was plank cutters connected to the mills. This means that if the grain milling capacity of the mill was just not needed and there was a sufficient amount of swollen water in the mill channel, the board was driven with the water. With technical progress, of course, much changed, and in the age of dualism, not only watermills and plank cutters but also steam industry equipment spread. This, in turn, required entrepreneurs. In the age of dualism, several nationally significant wood factories were established in the Dráva region. The timber industry, on the other hand, was not limited to estates at all. By the end of the $19^{\text {th }}$ century, with the help of local and external capital inflows, smaller and larger sawmills were established for the professional processing of wood.

In June 1882, in the very rapidly developing Barcs, the limited partnership Eugén Smith and Co. was registered as a wood merchant and wood saw owner in Barcs. Three years later,

\footnotetext{
24 Oroszi, S. (2010)

25 Bedő, A. (1896)

26 Kolossváryné Perényi, M. (1978): 187-188.
} 
following the opening of the Dráva Bridge in Barcs, the Paris-based company called Société d' importation de Chêne was established. ${ }^{27}$

Another enterprise was the Engel Adolf parquet factory in Pécs. ${ }^{28}$ Engel's wood companies were not only of local importance. At the regional level, it was one of the largest companies engaged in wood industry activities in and around Southern Transdanubia. They had fewer direct employees than the great manufacturers of the era, but the quality of the products produced was outstanding. Nothing proves this better than the fact that the Engel companies performed in prestigious places at several prestigious exhibitions. Perhaps the most significant of these successes was the gold medal at the World's Fair of Paris in 1878, which later made a significant contribution to making the company's name known. ${ }^{29}$

Although the name of Fabank (i.e. "Wood Bank") Plc. sounds completely unusual today, it is not a spelling mistake: the financial institution that operated more than a hundred years ago really had something to do with wood. The company was founded in 1878 by the French Société d'importation de Chêne. A few years later, the Neuschloss brothers in Budapest bought the disused wood factory from the French and continued wood processing, they also established the first wood factory in Pest. Their company later became involved in railway construction and then in aircraft manufacturing. The profile and operation of Neuschloss's Nasici (today: Nasice, Croatia) Tanning Factory and Steam Saw Plc. (Tannin = tannic acid) was expanding due to military orders. It also had sawmills in Susine-Gjurgjenovac, Satu Mare, Ljeskovica, Barcs and Homoród. There was also a barrel factory. Hazai Bank Plc. was the one who provided funding for a major capital increase in 1903. This bank was also responsible for financing the founding of the company in 1895. The company was known in the mid-1910s as one of the most important wood industry companies of the Austro-Hungarian Monarchy. ${ }^{30}$

The Budapest-based Fatermelő Plc., which had a branch in Rijeka, also had significant interests in the region. In terms of its Slavonian interests, it had a steam sawmill and parquet factory in Verőce and a steam sawmill and mechanical barrel factory in Bród. It even had plants in Galicia and Bosnia. It was basically established under the auspices of the Hungarian General Credit Bank, with the aim of extracting and processing the timber stock of the ducal estates of Schaumburg-Lippe. Its share capital was 1,800,000 K in 1916 after several capital increases. ${ }^{31}$ The following figure shows their ad:

The Hungarian-Slavonic Forestry Plc. was established in 1917 with a share capital similar to that of Fatermelö Plc. which, with its headquarters in Budapest, bought the estate and forest lands of Count Iván Draskovich for the purpose of extraction and further processing. ${ }^{32}$ The next larger company I examined in the region was Fakereskedelmi Plc., who worked only with barrels or coopers. In Berzence, they had a cooper wood warehouse. It was an old company. The founder of the company was Pfeiffer, a cooper maker, from whom Union Bank took over, then merged with the company of Lipót Kern in Budapest and took over the name of Fakereskedelmi Plc. From then on the CEO was Herman Neumann. Although the wood business was heavily influenced by the difficulties of the early $20^{\text {th }}$ century, with the tireless and prudent management of the board of directors, they still dominated the situation. ${ }^{33}$

The company was headquartered in Vienna. It also had a branch in Budapest. It had sawmills in Kalnica, Nagytopoly, Vinkovce, Zagreb, Banska Bystrica, Rezsőpart and Memphis Tenn,

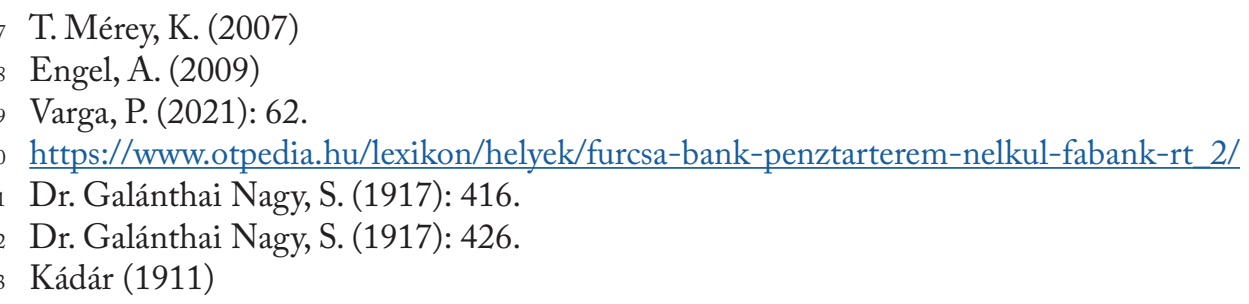


Picture 2. The advertisement of the Fakereskedelmi Plc.

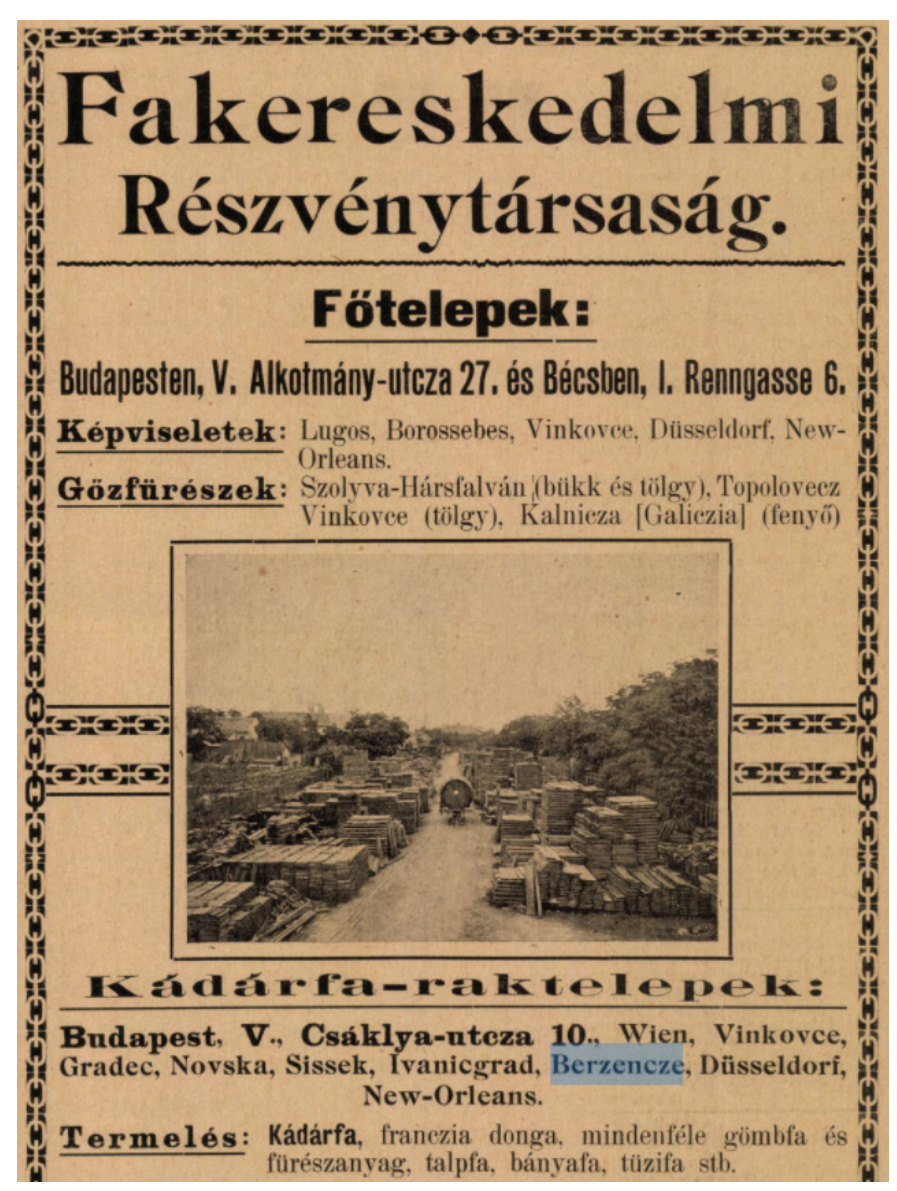

Source: Kádár (1911): 19. among others, while its share capital was $10,000,000 \mathrm{~K}$ in 1916 , and it was raised from 5,000,000 K in 1907 to this level. Its shares were also listed on the Budapest and Vienna stock exchanges. ${ }^{34}$

There was also another wood company in Berzence that I think is important to mention: the SomogyBerzence Wood and Stick Factory Plc., which is the predecessor of the Wood and Stick Factory Plc. with a headquarters in Budapest. It moved its headquarters to Berzence in 1911. The plant produced raw stick handles, semifinished and finished walking sticks and umbrella sticks, shoe poles and shoe heels. At that time, 200 workers were working in the plant. Furthermore, this company took over Kreisler's stick factory in Somogyberzence and the stick factory in Pakrác, which in 1908 was sold to the Slavonian Forestry Plc. In 1916, it had a registered capital of 500,000 K. The managing director was Géza Kreisler. ${ }^{35}$

By the early $20^{\text {th }}$ century, a large number of wood processing plants had been established across the country, though with different profiles and characteristics in each part of the country. The 1906 production survey showed 400 factory sawmills. Of these, 366 operated in Hungary and 34 in Croatian-Slavonia. Compared to 1898, the number of establishments increased by $77 \%$ in Hungary and by $25.9 \%$ in Croatia. There were 23 plants in Transdanubia and 34 plants in Croatian-Slavonia. ${ }^{36}$

One of the largest wood processing plants in Central Europe was on the Slavonian side of the Dráva, in Beliscse. (Beliscse was the name at the time, but it also appeared in the sources as Belisce and Belistye.) Henrik Gutmann's most significant and enduring enterprise was a wood processing plant in Beliscse on the Slavonian side of the Dráva, which he founded in 1884 . He started it, but after his death in 1890, his sons developed the plant into one with a European reputation. This large-scale capitalist enterprise was also inspired by Gutmann, Act 44 of 1881, which granted a 15-year tax exemption to developers of the manufacturing industry and the introduction of new industries, especially in ethnic areas. The location of the site was excellent: it was established in Verőce county, near the navigable section of the Dráva and near the railway lines. ${ }^{37}$ The contemporary Pallas Lexicon described the company as follows: "Here is one of the largest industrial plants on the continent, the Gutmann Vilmos and Alfréd company for wood sawing and tanning. The colony in B., which was created on some barren ground in the barren soil 8 years ago, is reminiscent of the most brilliantly successful American plantings. The plantations themselves make

34 Dr. Galánthai Nagy, S. (1917): 414-415.

35 Dr. Galánthai Nagy, S. (1917): 439.

36 Kolossváryné Perényi, M. (1978): 181.

37 Kerecsényi, E. (1979) 
up the whole city, with a church, a school, a hostel, long lines of workers' residences, a post office and a telegraph office with two large railway stations. The sawmill here is the largest plant in Europe in the oak industry. The loader is on the banks of the Drava, where wood, mostly destined for England, France and Belgium, is loaded onto tugs. The products of the tanning factory are mostly shipped abroad; it is also associated with a barrel factory and a wood chipper. Timber is transported to the site by a 142 $\mathrm{km}$ long industrial railway to Slavonia, now from its almost unparalleled primeval forests in Europe, formerly owned by the Majlath family (formerly Prandau)."38

The Gutmann brothers continued to expand the plant almost year after year.It is characteristic of its dimensions that at the turn of the $20^{\text {th }}$ century, it already employed 3,000 workers and operated 180 woodworking machines with a total capacity of 1,600 horsepower and 20 steam boilers. In order to ensure the supply of raw materials for the plant, huge estates were purchased mainly from Baron Prandau of Valpo along the Dráva, so they were finally able to process the trees of their own forests. 49,000 acres of forest were purchased in Vocin and 23,000 acres in Orahovica. ${ }^{39}$ According to a later figure, the size of their estates had already exceeded 100,000 acres, which also meant that the Gutmann family had taken possession of a vast estate along the Drava, and there was hardly a larger owner than them in the Slavonian territory. Life did not stop during the war in terms of their purchases, as Baron Gutmann's family bought the 4,000-acre forests around Slatina, part of the Schaumburg Lippe ducal estate, which Count Dánkovich had bought from the prince 2 years before. ${ }^{40}$

The size of sawmills is usually judged on the basis of the raw material and quantity processed based on the number and size of frame saws for processing, which are of course closely related to the amount of raw material processed. Taking all the sawmills together, an average of 15,452 $\mathrm{m}^{3}$ of wood fell per site. This average increased to $17,553 \mathrm{~m}^{3}$ for plants in Croatia, while it decreased to $15,175 \mathrm{~m}^{3}$ for plants in Hungary. Taking into account the types of each sawmill, one pine plant processed an average of $16,482 \mathrm{~m}^{3}$ of raw material, namely the Hungarian plants on average $16,578 \mathrm{~m}^{3}$ and the plants outside the Dráva / 7 plants / on average $15,669 \mathrm{~m}^{3}$, i.e. only about $5 \%$ less. An average of $5,573 \mathrm{~m}^{3}$ fell on a complete frame saw; the average on the Hungarian sites was $5,495 \mathrm{~m}^{3}$ and on the Croatian-Slavonian ones $8,437 \mathrm{~m}^{3}$. The utilization of the frame saw and work performance in Croatia was significantly better. There were 20 oak processing plants on one side of the Dráva and 15 on the other. In 1898, they processed 610,952 $\mathrm{m}^{3}$ of wood. On average, about $17,456 \mathrm{~m}^{3}$ of wood fell on one site. The average in Hungary was $15,586 \mathrm{~m}^{3}$ and in Croatia $19,949 \mathrm{~m}^{3} \cdot{ }^{41}$

\section{The trade of wood products}

The timber trade also developed significantly and transformed during the period under review. By the beginning of the $20^{\text {th }}$ century, there was an increasing view that, in addition to commercial and economic knowledge, commercial professionals in the wood industry should have other industry-specific knowledge. This goal was served, for example, by the fact that the steering committee of the Academy of Commerce in Budapest, together with the National Association of Hungarian Timber Traders and Woodworkers, organized a trade course in timber trade at the Budapest Academy of Commerce in 1903. The aim of the course was to provide the special knowledge required for the timber trade and to introduce students to all aspects of this part of the trade, theoretically and practically. ${ }^{42}$ The course lasted for one school year, i.e. ten months,

38 Pallas (1885): 44.; Kaposi, Z. (2014)

39 Kerecsényi, E. (1979): 157.; Kaposi, Z. (2020)

40 A Fakereskedelem (1915)

41 Kolossváryné Perényi, M. (1978): 181.

42 Az Ujság (1904) 
and included the following lectures and exercises: forestry, forest law, wood industry technology, wood trade techniques, customs, and various tariffs. In addition, students in the course could, depending on their needs and qualifications, listen to other subjects presented at the academy and participate in internships for academic students. In connection with the forestry lectures, study trips were organized to the main forest areas, in connection with the technological lectures to a larger sawmill, as well as to wood industry factories. ${ }^{43}$

Examining our main markets, it appears that most of France's oak needs, namely around 3/4 were covered by Hungary, and the rest was imported from Austria, Bosnia, Germany, Russia and the United States. ${ }^{44}$ The most extensive wood industry in France, both in terms of quantity and value, was barrel making and the cooperage industry. Let us also take into account that France was at that time the first among the wine-producing countries in the world, which only in barrels in 1898 was 1,294,373 hl. wine, and let us also take into account the domestic consumption and the demand for barrels for cognac, rum, cherry spirit, then we can form an idea for ourselves about this industry, especially in wine-growing regions, from small farms to large barrel factories. There was also a great need for wood-barreled barrels, to the extent that France had very large-scale sea fishing for herring, cod and other fish, smoked, salted or otherwise prepared, transported in barrels. ${ }^{45}$

Another important market for our wood industry was Germany. Mainly in the winegrowing regions, especially on the Rhine, there were many smaller cooperage plants, which also processed slag in Slavonia, Bosnia, and the Americas in the early $20^{\text {th }}$ century. The larger factories in Leipzig, Hamburg, Frankfurt, Frankenthal and Cassel mainly produced beer kegs, but also wine kegs. In general, American wood was mainly used to make large tubs and barrels, while Slavonian and Bosnian goods were used to make smaller barrels. The former was made mainly into beer kegs, and the latter was made mainly into wine kegs. ${ }^{46}$

The culmination of a spectacular boom in the timber industry was in the late $19^{\text {th }}$ and early $20^{\text {th }}$ centuries in the Dráva region. This period also marked the beginning of a recessionary period for the industry, resulting from the market and economic environment on the one hand, and large-scale imports of American wood raw materials into Europe at the time. By then, the situation in the hardwood business was no longer so favourable. As far as oak is concerned, the prices paid in the autumn of 1906 formed the zenith and already in the early spring a sluggish trend showed in oak products for construction purposes, especially the frieze. Turnover to barrels also declined and the sharp rise in prices came to an end. ${ }^{47}$

The reason why Slavonian oak was pushed into the background was also its high price. Furthermore, short and narrow sizes also contributed. As I have already mentioned, overseas oak boards were much cheaper than Hungarian and Slavonian ones, and this was compounded by the fact that America was transporting goods of such a size that it was really impressive compared to the smaller sizes in Hungary. ${ }^{48} \mathrm{An}$ additional difficulty for producers was what quality prices they achieved for their tree in this uncertain economic situation was in doubt because the market absorption capacity was very limited. ${ }^{49}$

The results and products of the estates of the examined area and the various wood industry companies were presented at several domestic and international exhibitions with great success

\footnotetext{
43 Iskolai értesítők (1903) (https://adt.arcanum.com/hu/view/Budapest B2088 B2133 1903/?query=Fakeres kedelem\&pg=151\&layout=s)

44 Kolossváryné Perényi, M. (1978): 103.

45 Same 138.

46 Same 83.

47 Magyar Fakereskedő (1908)

48 Magyar Fakereskedő (1908)

49 A Fakereskedelem (1913)
} 
in the examined period. However, it was important to be able to represent the results at an appropriate level within the country as well. This is why the national exhibition and fair held in Pécs between May and October of 1907 was important, where the country's craftsmen and tradesmen could present their latest products to the general public. The main organizers of the event were Miklós Zsolnay and the Chamber of Commerce and Industry of Pécs. Representatives from various industries held meetings during the exhibition, but there was also a congress of farmers, restaurateurs, winemakers and beekeepers. South Transdanubia's estates and timber companies were involved in a large number of forestry and timber industry topics. ${ }^{50}$

\section{Picture 3. Forestry pavilion at the national exhibition of Pécs in 1907}

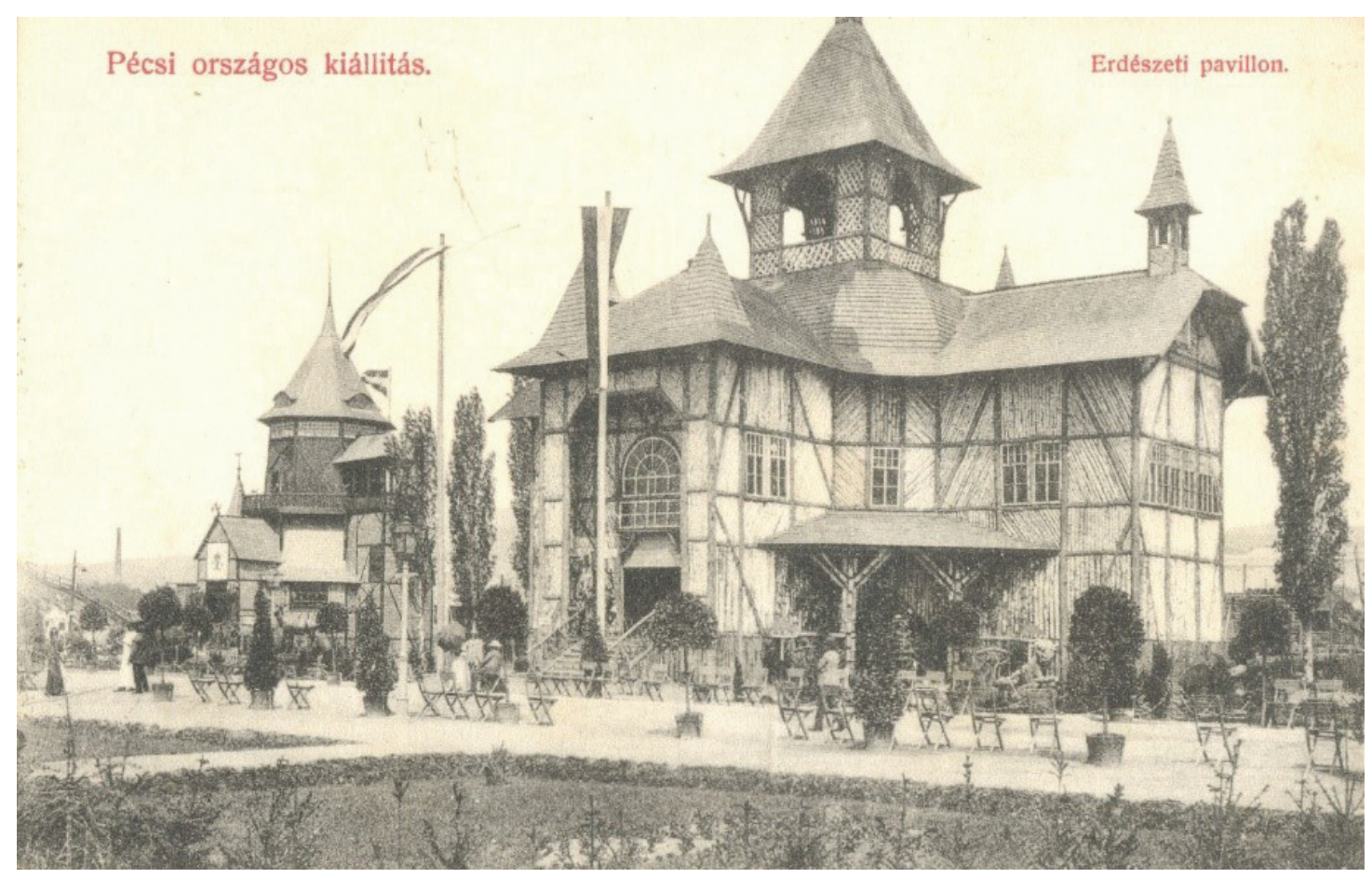

Source: https://mandadb.hu/cikk/809813/1907_evi_Pecsi_Orszagos_Kiallitas_es_Vasar

One of the most interesting venues of the exhibition in Pécs was the forestry pavilion. The exhibition pavilion, built of raw oak and birch in bark, was located on the side of the main road to the city. It would also be difficult to list the range of exhibitors and products on display. To mention a few, I mention that in addition to the forestry of Count István Széchényi in Kálmáncs, the forest manager of Count Tasziló Festetics in Csurgó also had their own stands. Also worth mentioning here are Count Iván Draskovich of Sellye and Prince SchaumburgLippe, the hunting and forestry products of the manor of Dárda. In addition to the exhibiting estates, there was also a large number of corporate exhibitors in the pavilion. For example, the varied and highly attractive beech products of the Slavonian company Strickler and Tscharner were also presented. The processing covered even the smallest detail, the best evidence of which was the beech carpets with a wide variety of patterns, which were made from small pieces of beech logs and were particularly popular in England. Going further, we could find the veneer and furniture slat products of the "Slavonia" Wood Producer Plc. ${ }^{51}$ In contrast there were the products of Guttmann S. H.'s Beliscian oak sawmill and tannin and wood distillery. ${ }^{52}$ The line of exhibitors could go on and on. We can state that all the major players in the wood industry in

\footnotetext{
50 Horváth, CS. (1998)

51 Dr. Galánthai Nagy, S. (1917): 433.

52 Erdészeti Lapok (1907)
} 
the region were represented at this event as exhibitors, presenting the diversity of the products produced and their internationally recognized quality. This will all go into the commercial chapter.

\section{Summary}

The forest was important to man at all ages, including the period and area I studied, when men of the age had to live and get used to the constant narrowing of forest benefits based on centuriesold traditions. The vast "primeval forests" along the Dráva, which were mainly pedunculate oaks, provided an extraordinary basis for the spread of professional forestry and the strengthening of its position among the estates in this region by the end of the $19^{\text {th }}$ century. In addition, they provided an important basis for the development of a modern wood industry, which is also suitable for the further processing of wood and is also suitable for international markets. It is also undeniable that the Forest Act of 1879 resulted in significant qualitative improvements in the long run in forest stocks and the management of estates. They wanted to curb the mindless deforestation aimed at making instant money, and they sought to raise domestic forest management practice quality to a higher level. That is why a network of forest inspectorates had been set up, which tried to influence farmers subject to the law through continuous inspections, licensing and possible penalties. As a result of the law, a new and positive process began, and by the end of the century, modern forest management of the age had developed in almost all of the estates. In the last decades of the $19^{\text {th }}$ century, thanks to high-quality, high-value forests, a large number of timber companies settled here or were established on local initiative. The recovery of the industry led to a boom in the demand side of wood products in this region. It can be seen from the above that the favourable external processes had a significant impact on local farming, as a result of which the proportion of forests in the Drava region compared to other cultivation branches decreased only in the short term by the beginning of the $20^{\text {th }}$ century. This was mainly in favour of arable land in this region as well. By this time, the peak of the wood industry boom in the life of the region can also be dated, as from the beginning of the century the purchase prices started to decrease greatly. In addition, a significant wave of bankruptcies was observed among timber companies and entrepreneurs. The mood of the professional audience of the age was greatly influenced by this process. Sudden and high levels of mistrust and uncertainty entered the daily lives of market participants with great force. This was mainly due to negative developments and changes in international markets. In addition, oak products imported from the Americas appeared in increasing volumes on European markets, flooding the markets at lower prices and in more processable sizes.

\section{Bibliography}

Bedő, A. (1896): A magyar állam erdőségeinek gazdasági és kereskedelmi leírása. Vol. 1-3. Budapest Bellye (1883): Albrecht föherceg bellyei uradalmának leírása. Bécs

Csorba, J. (1857): Somogy vármegye ismertetése. Pest

Ditz, H. (1993): A magyar mezógazdaság. Budapest

Dr. Galánthai Nagy, S. (1912): Nagy Magyar Compass. XL. Anniversary Grade 1913/13. Budapest

Dr. Galánthai Nagy, S. (1917): Nagy Magyar Compass. XLIV. Grade 1916-17. Financial and Trade Yearbook. II. Part. Budapest

Edvi Illés, A. (1911): A magyar korona országainak gyáripara az 1906. évben. II. Volume. 2. Part. Fém-, fa- és gépipar s ezekkel rokon iparok. Budapest

Engel, A. (2009): Életemböl. Pécs 
Engel, S. (1882): Magyarország Faipara és Fakereskedése. Technikai, Gazdasági és statistikai közlemények fakereskedők, faiparosok, erdészek stb. számára. Budapest

Engel, Alexander (1892): Österreichs Holz-Industrie und Holzhandel. Wien.

Erdészettörténet. Dr. h.c. Dr. Márkus László és Dr. A. Sz. Tyihonov előadásainak alapján. Sopron. In: http://www.emk.nyme.hu/uploads/media/Erd\%C3\%A9szett\%C3\%B6rt\%C3\%A9net 2011.pdf

Erdősi, F. (1978): A Dél-Dunántúl közlekedési hálózatának kialakulása és szerepe a terület régióvá válásában. In: Baranya, Somogy, Tolna és Zala megyék regionális tudományos tanácskozása. (Edited by Kanyar,J.) Kaposvár

Harasztia, A. (2005): Barcs közlekedése a dualizmus korában, középpontban a vasúti közlekedés. Szombathely Hirsch, A. (1903): Somogy vármegye gazdasági monographiája. Budapest: Grill

Horváth, CS. (1998): A múzeum helytörténeti gyújteményében lévó, Pécset ábrázoló képes levelezólapok. VI. A Pécsi Országos Kiállitás és Vásár, 1907. Janus Pannonius Museum Évkönyve 41-42. Pécs

Kaposi, Z. (2007): Die Entwicklung der Wirtschaft und Gesellschaft in Ungarn 1700-2000. Passau: Schenk Verlag

Kaposi, Z. (2012): Az agrárkonjunktúra hatása a nagykanizsai uradalom erdógazdálkodására (1850-1914). Közép-Európai Közlemények 5. (2012) 2. issue. 178-187.

Kaposi, Z. (2013): Egy szlavóniai nagybirtok gazdasági vonatkozásai (18-19. század). Közép-Európai Közlemények 6. (2013) 3. issue. 64-76.

Kaposi, Z. (2019): Uradalmak, földbirtokosok és birtokforgalom a Dél-Dunántúlon a 19. században. Mezőgazdaságtörténeti Tanulmányok 14. Budapest

Kaposi, Z. (2020/a): Forstbewirtschaftung in der zweiten Hälfte des 19. Jahrbunderts in Nagykanizsa und Umgebung. In: Malli, Rüdiger - Moll, Martin - Ruhri, Alois (eds.): Der Wald als Lebens- und Wirtschaftswachstum im pannonischen Raum - Forests as living space and economic sphere in the Pannonian region. Mogersdorf 47. Graz: Das Land Steiermark 80-94.

Kaposi,Z.(2020/b):A Dráva menti uradalmakgazdasági változásai a Trianon körüli években. Agrártörténeti Szemle - Historia Rerum Rusticarum. 61. (2020) 1-4. 1-24.

Kerecsényi, E. (1979): A nagykanizsai Gutmann-család felemelkedése a nagyburzsoáziába. In: Közlemények Zala megye közgyüjteményeinek kutatásaiból. Zalai Gyújtemény 12. Zalaegerszeg. 147-166.

Kolossváryné Perényi, M. (1978): A faipar története Magyarországon. Az Országos Erdészeti Egyesület Erdészettörténeti Szakosztálya Közleményei 11-12. Budapest

Magyar, E. (1981): Településszerkezet és agrártermelés Somogy megyében a 18. században és a 19. század elsó felében. In: Kanyar J. (Ed.): Somogy megye múltjából. Levéltári Évkönyv 12. Kaposvár

Nagyváthy, J. (1821): Magyar practicus termesztô. Pest

Oroszi, S. (2010): A fa Erdélyben - A bölcsőtól a koporsóig. Erdészettörténeti Közlemények LXXXII. Országos Erdészeti Egyesület Erdészettörténeti Szakosztály. Budapest

Pártos, Sz. (1941): A magyar gyáripar évkönyve és címtára, 1941. Budapest

Szabó, M. (2019): Az 1879. évi erdótörvény hatása a Dráva menti uradalmi erdógazdálkodás és faipar fejlódésére. Agrártörténeti Szemle - Historia Rerum Rusticarum, 60. (2019) 1-4. issue.

Szterényi, J. (1901): A magyar korona országainak gyáripara az 1898. évben. Booklets 9-10. Faipar I-II. Budapest

T.Mérey, K. (2007): Somogy megye gazdasága és társadalma a dualizmus korában. In:T.Mérey, K.:Település - megye - régió. Pécs: MTA RKK. 119-172.

T. Mérey, K. (1963): Az erdógazdálkodás Somogy megyében (1700-1879). Agrártörténeti Szemle - Historia Rerum Rusticarum, 5. (1963) No. 1-2.133-152.

Tóth, P. (1988): Somogy megye leírása 1812-böl. In: Kanyar J. (Ed.): Somogy megye múltjából. Levéltári Évkönyv 18. Kaposvár

Ujváry, I. (1914): Mezógazdaság, állattenyésztés, szôlőmivelés, erdészet. In: Csánki D. (Ed.): Magyarország vármegyéi és városai. Somogy. Budapest 
Varga, P. (2021): A ceruzakereskedéstól a komlói szénbányászat megteremtéséig. Engel Adolf vállalkozásai az 1840-es évektól az I. világháborúig. In: Pelles, M. - Jakopánecz, E. - Kaposi, Z. (eds.): Úton a jövőbe. Pécsi Tudományegyetem, Közgazdaságtudományi Kar. Pécs. 56-68.

\section{Contemporary newspapers and magazines:}

A Fakereskedelem, 1913 (3. grade, 3-24. issue) 25-08-1913 / 16. issue 5.

A Fakereskedelem, 1915 (5. grade, 1-51. issue) 10-06-1915 / 22-23. issue 3.

Az Ujság, 1. July 1904. (2. grade, 181-195. issue) 09-07-1904 / 189. issue 19.

Barcs és Vidéke, 3.11.1903.

Erdészeti Lapok (1907): 46. grade 16. booklet.

Hajós Naptár (1900)

Kádár, 1911 (6. grade, 1-12. issue) 31-05-1911 / 5. issue 4.

Magyar Fakereskedő, 1908 (15. grade, 1-24. issue) 01-01-1908 / 1. issue 5.

Magyar Fakereskedő, 1908 (15. grade, 1-24. issue) 15-01-1908 / 2. issue 6.

Magyar Fakereskedő, 1908 (15. grade, 1-24. issue) 15-01-1908 / 2. issue 4.

Vízügyi és Hajózási Közlöny, 1907. 41. issue. 322.

\section{Other internet sources:}

https://www.otpedia.hu/lexikon/helyek/furcsa-bank-penztarterem-nelkul-fabank-rt 2/

https://mandadb.hu/cikk/809813/1907 evi Pecsi Orszagos Kiallitas es Vasar

http://www3.arcanum.hu/onap/opt/a110616.htm?v=pdf\&q=WRD\%3D\%28schaumburg

https://adt.arcanum.com/hu/view/Budapest B2088 B2133 1903/?query=Fakeres $\underline{\text { kedelem\&pg }=151 \& \text { \&layout }=\mathrm{s}}$ 